\title{
LENGTH-WEIGHT RELATIONS OF 24 FISH SPECIES (ACTINOPTERYGII) FROM HIRAKUD RESERVOIR, ODISHA STATE OF INDIA
}

\author{
Subodha K. KARNA ${ }^{1}$, George N. KATSELIS ${ }^{2 *}$, and Laith A. JAWAD ${ }^{3}$ \\ ${ }^{1}$ ICAR — Central Inland Fisheries Research Institute, Barrackpore, Kolkata, India \\ ${ }^{2}$ Department of Fisheries-Aquaculture Technology, Technological Educational Institute of Western Greece, 30200, \\ Mesolonghi, Greece \\ ${ }^{3} 4$ Tinturn Place, Flat Bush, Manukau, Auckland 2016, New Zealand
}

Karna S.K., Katselis G.N., Jawad L.A. 2018. Length-weight relations of 24 fish species (Actinopterygii) from Hirakud Reservoir, Odisha State of India. Acta Ichthyol. Piscat. 48 (1): 83-86.

\begin{abstract}
Length-weight relations were estimated for 24 fish species sampled from the Hirakud Reservoir (Odisha State, India): Salmostoma bacaila (Hamilton, 1822); Salmostoma phulo (Hamilton, 1822); Labeo rohita (Hamilton, 1822); Labeo bata (Hamilton, 1822); Cirrhinus reba (Hamilton, 1822); Labeo calbasu (Hamilton, 1822); Puntius sophore (Hamilton, 1822); Puntius chola (Hamilton, 1822); Pethia ticto (Hamilton, 1822); Systomus sarana (Hamilton, 1822); Pethia phutunio (Hamilton, 1822); Osteobrama cotio (Hamilton, 1822); Amblypharyngodon mola (Hamilton, 1822); Rasbora rasbora (Hamilton, 1822); Parambassis ranga (Hamilton, 1822); Parambassis lala (Hamilton, 1822); Channa punctata (Bloch, 1793); Macrognathus pancalus (Hamilton, 1822); Notopterus notopterus (Pallas, 1769); Chanda nama (Hamilton, 1822); Xenentodon cancila (Hamilton, 1822); Glossogobius giuris (Hamilton, 1822); Ompok bimaculatus (Bloch, 1794); Gudusia chapra (Hamilton, 1822). They represented 10 families: Cyprinidae (14 species), Ambassidae (2 species), Channidae, Mastacembelidae, Notopteridae, Centropomidae, Belonidae, Gobiidae, Siluridae, and Clupeidae (1 species each). The $b$ values ranged from 2.62 to 3.44. Nine of the species displayed isometric growth $(b=3)$, seven species negative allometric growth $(b<3)$, and eight species represented positive allometric growth $(b<3)$. New maximum lengths are provided for two species.
\end{abstract}

Keywords: Length-weight relations, Hirakud reservoir, Cyprinidae, Ambassidae, Channidae

In fish biology, length and weight are two basic morphological traits at the individual as well as at the population level. The weight of fishes is closely related to their length and it determines whether somatic growth was isometric or allometric (Le Cren 1951, Froese 2006, Froese et al. 2011). Length-weight relation (LWR) has been used widely for fisheries management and conservation. It provides information on the condition factor and somatic growth type (isometric or allometric) of fish species (Le Cren 1951, Froese 2006, Froese et al. 2011) and therefore it is used for the determination of the biomass, enabling the conversion of length to weight. This relation has also been used in life history studies (Petrakis and Stergiou 1995, Froese 2006, Froese et al. 2011), for comparison of species growth between sexes, different seasons, and regions (Froese 2006, Moutopoulos et al. 2013) as well as an index of habitat trophic state (Tsoumani et al. 2006, Moutopoulos et al. 2011).

From the last decade, there has been an increasing interest in the scientific literature regarding fish lengthweight relations (Froese et al. 2011). Up to now, from
33500 fish species reported in FishBase, LWRs of 4793 species $(14.3 \%$ of species) is available from this database (Froese and Pauly 2017).

Hirakud (Dam) Reservoir $\left(21^{\circ} 30^{\prime}-21^{\circ} 50^{\prime} \mathrm{N}, 83^{\circ} 30^{\prime}-\right.$ $84^{\circ} 05^{\prime} \mathrm{E}$ ) is the first major multi-purpose river valley project in India. Country's largest (in area) man-made reservoir (or Lake), the Hirakud (25.8 km long) is situated on the Mahanadi River of Odisha State has a surface area of $743 \mathrm{~km}^{2}$.

In the presently reported study, LWR parameters have been estimated for 24 fish species sampled from the Hirakud Reservoir, representing the following families: Cyprinidae (14 species), Ambassidae (2 species), Channidae, Mastacembelidae, Notopteridae, Centropomidae, Belonidae, Gobiidae, Siluridae, and Clupeidae (1 species each) (Table 1). For these species, information about LWRs is limited. For one species, namely Osteobrama cotio (Hamilton, 1822), there is no records of LWRs, while for thirteen species there are one to three records, for six species three to six records, and for three species seven to ten LWR records in FishBase 
(Froese and Pauly 2017; 13 Aug 2017), respectively. The relevant FishBase data come from freshwater bodies of the Indian subcontinent, Indonesia, China, Taiwan, and South Africa. Regarding the conservation status, 22 species were ranked in the IUCN Red List of Threatened Species (Anonymous 2017) as least concern (LC) and two-Parambassis lala (Hamilton, 1822) and Ompok bimaculatus (Bloch, 1794) —as near threatened (NT) (Table 1).

Fish samples were collected during June-July 2015 (monsoon), November-December 2015 (post-monsoon), and February 2016 (pre-monsoon). The samples were collected by fishermen using the most common fishing gears in the Hirakud reservoir i.e., cast nets, gill nets, stake nets with long lines, and shore seines. After collection, the specimens were brought to the research laboratory in polythene bags. The fish species were confirmed by following Day (1876), Talwar and Jhingran (1991), and Jayaram (1999) and measured for total length $(L)$ to the nearest $0.01 \mathrm{~cm}$ with a digital calliper and weight $(W$; wet weight) to the nearest $0.01 \mathrm{~g}$ with digital balance.

Length-weight relations were estimated using the equation:

$$
W=a L^{b}
$$

where $a$ and $b$ are the equation parameters calculated by the least squares method using the logarithmic form of the equation:

$$
\log W=\log a+b \cdot \log L
$$

The statistical significance level of the coefficient of determination $\left(r^{2}\right)$ and 95\% confidence intervals (95\%CI) of $a$ and $b$ were also estimated (Zar 1999). Obvious outliers were identified and removed, according to the plot of the $\log W$ over $\log L$ (Froese 2006). The $b$ value of each species was tested by Student's $t$-test (Zar 1999) to verify if it was significantly different from isometric growth $(b=3, P<0.05)$ (Froese et al. 2011).

A total of 2626 fish individuals were measured. The species name, sample size $(n), L$ and $W$ ranges, intercept $a$, slope $b, 95 \%$ confidence intervals of $a$ and $b, P$ values of $b$ and coefficient of determination $\left(r^{2}\right)$ are summarized in Table 2. The length and weight data were pooled together for each species without sampling site and sex discrimination. The sample size ranged from 6 individuals

Table 1

\begin{tabular}{|c|c|c|c|c|c|}
\hline Family & Species & Common name & FishBase & Countries & IUCN \\
\hline \multirow[t]{14}{*}{ Cyprinidae } & Salmostoma bacaila (Hamilton, 1822) & Large razorbelly minnow & 1 & $\mathrm{BD}$ & $\mathrm{LC}$ \\
\hline & Salmostoma phulo (Hamilton, 1822) & Finescale razorbelly minnow & 1 & $\mathrm{BD}$ & $\mathrm{LC}$ \\
\hline & Labeo rohita (Hamilton, 1822) & Roho labeo & 7 & $\mathrm{IN}, \mathrm{PH}, \mathrm{BD}$ & $\mathrm{LC}$ \\
\hline & Labeo bata (Hamilton, 1822) & Bata & 1 & $\mathrm{BD}$ & $\mathrm{LC}$ \\
\hline & Cirrhinus reba (Hamilton, 1822) & Reba carp & 3 & $\mathrm{BD}$ & $\mathrm{LC}$ \\
\hline & Labeo calbasu (Hamilton, 1822) & Orangefin labeo & 4 & $\mathrm{IN}, \mathrm{BD}$ & $\mathrm{LC}$ \\
\hline & Puntius sophore (Hamilton, 1822) & Pool barb & 5 & IN, BD & $\mathrm{LC}$ \\
\hline & Puntius chola (Hamilton, 1822) & Swamp barb & 3 & LK, IN & $\mathrm{LC}$ \\
\hline & Pethia ticto (Hamilton, 1822) & Ticto Barb & 5 & $\mathrm{BD}, \mathrm{IN}$ & $\mathrm{LC}$ \\
\hline & Systomus sarana (Hamilton, 1822) & Olive barb & 3 & LK, IN & $\mathrm{LC}$ \\
\hline & Pethia phutunio (Hamilton, 1822) & Spottedsail barb & 1 & IN & $\mathrm{LC}$ \\
\hline & Osteobrama cotio (Hamilton, 1822) & & 0 & & $\mathrm{LC}$ \\
\hline & $\begin{array}{l}\text { Amblypharyngodon mola (Hamilton, } \\
\text { 1822) }\end{array}$ & Mola carplet & 4 & $\mathrm{BD}, \mathrm{IN}$ & $\mathrm{LC}$ \\
\hline & Rasbora rasbora (Hamilton, 1822) & Gangetic scissortail rasbora & 1 & IN & $\mathrm{LC}$ \\
\hline \multirow[t]{2}{*}{ Ambassidae } & Parambassis ranga (Hamilton, 1822) & Indian glassy fish & 1 & $\mathrm{BD}$ & $\mathrm{LC}$ \\
\hline & Parambassis lala (Hamilton, 1822) & Highfin glassy perchlet & 2 & $\mathrm{BD}, \mathrm{IN}$ & NT \\
\hline Channidae & Channa punctata (Bloch, 1793) & Spotted snakehead & 10 & $\mathrm{BD}, \mathrm{IN}$ & $\mathrm{LC}$ \\
\hline Mastacembelidae & $\begin{array}{l}\text { Macrognathus pancalus (Hamilton, } \\
1822 \text { ) }\end{array}$ & Barred spiny eel & 1 & $\mathrm{BD}$ & LC \\
\hline Notopteridae & Notopterus notopterus (Pallas, 1769) & Bronze featherback & 7 & IN, TW, PK & $\mathrm{LC}$ \\
\hline Centropomidae & Chanda nama (Hamilton, 1822) & Elongate glass-perchlet & 1 & $\mathrm{BD}$ & $\mathrm{LC}$ \\
\hline Belonidae & Xenentodon cancila (Hamilton, 1822) & Freshwater garfish & 1 & $\mathrm{TH}$ & $\mathrm{LC}$ \\
\hline Gobiidae & Glossogobius giuris (Hamilton, 1822) & Tank goby & 7 & $\mathrm{CN}, \mathrm{PH}, \mathrm{ID}, \mathrm{BD}, \mathrm{ZA}$ & LC \\
\hline Siluridae & Ompok bimaculatus (Bloch, 1794) & Butter catfish & 4 & IN & NT \\
\hline Clupeidae & Gudusia chapra (Hamilton, 1822) & Indian river shad & 4 & $\mathrm{BD}, \mathrm{IN}$ & LC \\
\hline
\end{tabular}

List of fish species sampled from Hirakud Reservoir, Odisha State, India

FishBase $=$ LWR record in FishBase (Froese and Pauly 2017; 13 Aug 2017); BD = Bangladesh, IN $=$ India, $P H=$ Philippines, $L K=$ Sri Lanka, $\mathrm{TW}=$ Taiwan, $\mathrm{TH}=$ Thailand, $\mathrm{PK}=$ Pakistan, $\mathrm{CN}=$ China, $\mathrm{ID}=$ Indonesia, $\mathrm{ZA}=$ South Africa; $\mathrm{IUCN}=\mathrm{IUCN}$ Conservation Status: $\mathrm{CR}=$ critically endangered, $\mathrm{EN}=$ endangered, $\mathrm{LC}=$ least concern, $\mathrm{NT}=$ near threatened. 


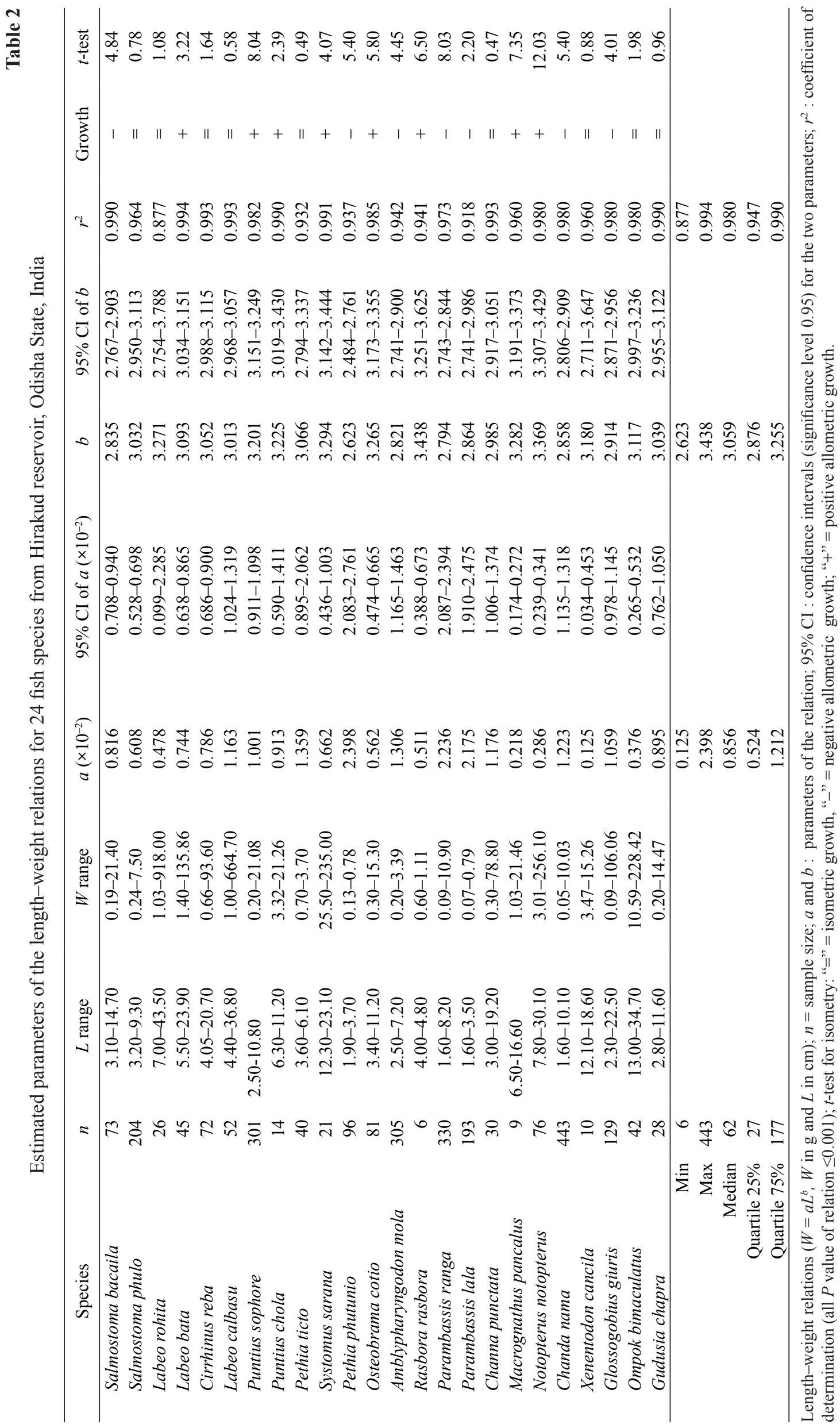


for Rasbora rasbora and 9 for Macrognathus pancalus to 330 for Parambassis ranga and 443 for Chanda nama.

All relations were statistically significant $(P<0.001)$, with high $r^{2}$ values ranging from 0.877 (Labeo rohita) to 0.994, with median value 0.980 . For five species (Labeo bata, Cirrhinus reba, Labeo calbasu, Systomus sarana, and Channa punctata) the estimated $r^{2}$ were higher than 0.991 .

The $a$ values obtained ranged from 0.00125 (Xenentodon cancila) to 0.0239 (Pethia phutunio). The median value of $a$ was 0.00856 while the $50 \%$ of central values (values included between the quartiles of $25 \%$ and $75 \%$ ) ranged from 0.00524 to 0.01211 . The values of $b$ ranged from 2.623 for $P$. phutunio to 3.438 for $R$. rasbora. The median of $b$ was 3.059 while the $50 \%$ of central values ranged from 2.876 to 3.255 .

For the 14 species, the $a$ and $b$ values cited in FishBase (Froese and Pauly 2017) were on the 95\% CI of $a$ and $b$ estimated in the presently reported study. For Puntius chola, $R$. rasbora and Macrognathus pancalus the $b$ values cited in FishBase (Froese and Pauly 2017) were lower than the lowest of $95 \%$ CI of estimated $b$ while for the Cirrhinus reba and Amblypharyngodon mola were higher than the upper limit of $95 \%$ CI of estimated $b$, respectively. A number of factors are known to influence the LWR in fish (i.e., habitat, growth phase, season, the degree of stomach fullness, gonad maturity, sex, size range, health, fish condition, and preservation techniques) (Froese 2006). In particular, for the three above-mentioned species, the $b$ values could be considered overestimated due to that the small number of sample $(14,6$, and 9 individuals, respectively) and to that they cover a narrow range of length (Froese 2006). In all cases, described $b$ values correspond to the observed length ranges and so, extrapolation of these parameters to different length ranges or seasons should be handled with caution (Petrakis and Stergiou 1995).

Nine of the species displayed isometric growth $(b=$ $3)$, seven species negative allometric growth $(b<3)$ and eight species positive allometric growth $(b<3)$. To the best of our knowledge, herein, new maximum lengths are presented for P. phutunio $\left(L_{\max }=37 \mathrm{~mm}\right) R$. rasbora $\left(L_{\max }\right.$ $=48 \mathrm{~mm}$ ).

\section{ACKNOWLEDGEMENTS}

We would like to thank the ICAR - Central Inland Fisheries Research Institute, India for giving us the opportunity to work on the fish samples obtained from Hirakud Reservoir.

\section{REFERENCES}

Anonymous 2017. The IUCN Red List of Threatened Species. Version 2017-1. [Downloaded on 12 May 2017] http://www.iucnredlist.org

Day F. 1876. The fishes of India being a natural history of the fishes known to inhabit the seas and fresh waters of India, Burma, and Ceylon. Volume I. Bernard Quaritch, London, England. DOI: 10.5962/bhl.title.62705

Froese R. 2006. Cube law, condition factor and weightlength relationships: History, meta-analysis and recommendations. Journal of Applied Ichthyology 22 (4): 241-253. DOI: 10.1111/j.1439-0426.2006.00805.x

Froese R., Pauly D. (eds.) 2017. FishBase. [Version 02/2017] http://www.fishbase.org

Froese R., Tsikliras A.C., Stergiou K.I. 2011. Editorial note on weight-length relations of fishes. Acta Ichthyologica et Piscatoria 41 (4): 261-263. DOI: 10.3750/AIP2011.41.4.01

Jayaram K.C. 1999. The fresh water fishes of the Indian region. Narendra Publishing House, Delhi, India.

Le Cren E.D. 1951. The length-weight relationship and seasonal cycle in gonad weight and condition in the perch (Perca fluviatilis). Journal of Animal Ecology 20 (2): 201-219. DOI: 10.2307/1540

Moutopoulos D.K., Koukou K., Vavarouta V., Ramfos A., Katselis G. 2011. Investigation of length-weight relationships for 10 commercial fish species as a possible trophic state index of coastal lagoons. Acta Adriatica 52 (2): 261-268.

Moutopoulos D.K., Ramfos A., Mouka A., Katselis G. 2013. Length-weight relations of 34 fish species caught by small-scale fishery in Korinthiakos Gulf (central Greece). Acta Ichthyologica et Piscatoria 43 (1): 57-64. DOI: 10.3750/AIP2013.43.1.08

Petrakis G., Stergiou K.I. 1995. Weight-length relationships for 33 fish species in Greek waters. Fisheries Research 21 (3-4): 465-469. DOI: 10.1016/0165-7836(94)00294-7

Talwar P.K., Jhingran A.G. 1991. Inland fishes of India and adjacent countries. Vol. 2. IBH, New Delhi, India.

Tsoumani M., Liasko R., Moutsaki P., Kagalou I., Leonardos I. 2006. Length-weight relationships of an invasive cyprinid fish (Carassius gibelio) from 12 Greek lakes in relation to their trophic states. Journal of Applied Ichthyology 22 (4): 281-284. DOI: $10.1111 /$ j.1439-0426.2006.00768.x

Zar J.H. 1999. Biostatistical analysis. 4th edn. Prentice Hall, Upper Saddle River, NJ, USA.

Received: 11 June 2017 Accepted: 26 December 2017 Published electronically: 31 March 2018 